\title{
PENGARUH PERILAKU DAN BUDAYA ORGANISASI TERHADAP ETOS KERJA GURU SEKOLAH MENENGAH PERTAMA NEGERI
}

\author{
Sutarja Fahrudin \\ STKIP Muhammadiyah Kuningan Jawa Barat. Email: sutarjafahrudin1967@gmail.com
}

Received: December 21, 2020, reviewed December 30, 2020, published Apr 30, 2020

Citation: Ratnaningrum. (2020). Pengaruh Perilaku dan Budaya Organisasi Terhadap Etos Kerja Guru Sekolah Menengah Pertama Negeri. Edum Journal, 3(1)

\begin{abstract}
ABSTRAK
Penelitian ini telah dilaksanakan dan dianalisis dengan mengambil fokus utama pada perilaku dan budaya organisasi serta pengaruhnya terhadap etos kerja guru. Metode yang digunakan adalah metode survey di mana penulis terjun langsung ke tataran empirik dengan menyebarkan angket terhadap 62 orang.Teknik pengolahan dan analisis yang digunakan adalah regresi. Hasil penelitian menunjukkan bahwa: (1) Terdapat pengaruh yang positif dan signifikan perilaku organisasi terhadap etos kerja guru. (2) Terdapat pengaruh yang positif dan signifikan budaya organisasi terhadap etos kerja. (3) Terdapat pengaruh yang positif dan signifikan perilaku dan budaya organisasi secara bersama-sama (simultan) terhadap etos kerja guru. Bertolak dari kesimpulan tersebut penulis menyarankan, bahwa: (1) Etos kerja harus diupayakan selalu dalam kondisi bagus. Pada sisi perilaku organisasi dimensi komunikasi perlu ditingkatkan melalui program pertemuan rutin dengan guru dan memperbanyak kebersamaan. Pada sisi budaya organisasi kepala sekolah disarankan untuk memberikan peluang lebih banyak kepada guru agar berinovasi dan berkreasi.
\end{abstract}

\section{Kata Kunci: Perilaku Organisasi, Budaya Organisasi, Etos Kerja Guru}

\begin{abstract}
This research has been carried out and analyzed by taking the main focus on organizational behavior and culture and its influence on the teacher's work ethics. The method used is a survey method in which the writer plunges directly into the empirical level by distributing questionnaries to 62 people. The processing and analysis technique used in regression. The result showed that: (1) There was a positive and significant influence on organizational behavior on the theacher's work ethic. (2) There is a positive and significant influence of organizational culture on work ethic. (3) There is a positive and significant influence of organizational behavior and culture together (simultaneously) on the teacher's work ethic. Starting from this conclusion the authors suggest, that: (1) The work ethic must always be sought in good condition. On the organizational behavior, the dimension of communication needs to be improved through regular meetings with the teacher and increasing togetherness. On the culture side of the principal's organization it is advisable to provide more opportunities for teachers to innovate and be creative.
\end{abstract}

Keywords: Organizational Behavior, Organizational Culture, Teacher's Work Ethic

\section{PENDAHULUAN}

Pendidikan adalah usaha sadar dan terencana untuk mengembangkan potensi diri siswa. Hal ini terdapat dalam Undang Undang Republik Indonesia Nomor 20 tahun 2003 tentang sistem pendidikan nasional. Peran pendidikan dalam dinamika bernegara dapat dilihat pada konsep pendidikan itu sendiri bahwa melalui pendidikanlah potensi diri warga negara dapat berkembang. Potensi yang berkembang dari individu-individu warga negara bersinergi menjadi potensi nasional yang mewujudkan kemajuan suatu negara termasuk Indonesia. Pendidikan terjadi di lingkungan keluarga, lingkungan masyarakat sekitar dan di sekolah-sekolah atau satuan pendidikan. Sekolah merupakan tempat terjadinya proses pendidikan secara formal. Setiap proses belajar mengajar diharapkan mampu mengembangkan peserta 
didik sehingga tercapai tujuan pendidikan. Pada dasarnya, pelaksanaan proses belajar mengajar dapat terlaksana dengan baik apabila faktor-faktor yang berkaitan dengan kegiatan pembelajaran seperti peserta didik, pendidik, sarana dan prasarana pendidikan saling mendukung. Guru yang berperan sebagai pendidik dinilai memegang peranan penting demi tercapainya kualitas proses belajar mengajar yang diharapkan. Guru harus bekerja secara efisien, efektif dan produktif. Secara keseluruhan guru harus mencapai kinerja yang bagus. Kinerja guru yang bagus bisa dicapai salah satunya adalah guru harus memiliki etos kerja yang tinggi.

Salah satu upaya yang harus dilakukan oleh para pengelola sekolah adalah dengan membentuk sekolah sebagai suatu organisasi pendidikan yang bersifat kondusif dengan mengembangkan suasana demokratis di kalangan personilnya yang meliputi staf tata usaha dan tenaga pendidik atau guru. Suasana kondusif sangat diperlukan mengingat semakin beratnya tuntutan masyarakat terhadap kualitas sekolah, sedangkan pengelola atau kepala sekolah tidak akan mampu untuk menjawab tuntutan tersebut tanpa menjalin kerjasama yang baik dengan setiap personil sekolah, terutama sekali para guru.

Untuk membentuk budaya organisasi (sekolah) yang efektif, seluruh pemangku kepentingan di sekolah perlu memahami dan bergerak dalam suatu kesamaan visi dan misi sekolah. Budaya organisasi di sekolah atau budaya sekolah merupakan nilai-nilai, kepercayaan, dan tindakan sebagai hasil kesepakatan bersama yang melahirkan komitmen seluruh personil untuk melaksanakannya secara konsekuen dan konsisten. Budaya sekolah harus kondusif dengan memperhatikan berbagai potensi bagi pemberdayaan segenap sumber daya yang ada secara optimal dan memberikan kesempatan bagi setiap personil untuk berkreasi dan berinovasi di dalam pelaksanaan tugasnya sesuai dengan visi dan misi sekolah. Dengan demikian budaya yang positif akan mempengaruhi pengembangan diri dan kompetensi profesional setiap personil dalam upaya proses peningkatan mutu sekolah khususnya dan mutu pendidikan secara umum.
Bekerja sesungguhnya merupakan bagian penting dari kehidupan manusia. Menurut Sinamo (2002:54-56), melalui bekerja orang ingin mencapai tujuan-tujuan sebagai berikut: "(1) dengan bekerja manusia akan mendapatkan nafkah untuk dapat memenuhi kebutuhan hidupnya; (2) orang bekerja agar bisa menabung untuk kebutuhan masa depan; (3) dengan bekerja manusia dapat membangun karier cemerlang untuk memperoleh jabatan yang memberikan status sosial, kehormatan, dan kepuasan batin; (4) bekerja merupakan sarana menyumbangkan karya nyata kepada masyarakat menuju suatu kemajuan; (5) bekerja merupakan sarana ekspresi diri secara kreatif dan artistik; (6) bekerja sebagai usaha mengaktualisasikan potensi bio-psiko-spiritualnya sccara maksimal; (7) bekerja sebagai wahana pengabdian bagi sebuah idealisme; dan (8) melalui pekerjaan orang juga ingin mengekspresikan rasa tanggung jawab dan rasa syukur atas kehidupannya. Dengan demikian, bekerja merupakan hakekat hidup manusia dan merupakan kebutuhan hidup paling mendasar".

Etos kerja "merupakan sikap hidup yang bersedia bekerja keras, penuh semangat untuk mampu menolong diri sendiri atau mandiri, berpola hidup sederhana, mampu bekerja sama dengan sesama manusia atas dasar gotong royong dan kekeluargaan serta selalu berpikir kreatif dan maju" (Soeharsono Sagir, 2000:63).

Tasmara (2001:29), mengemukakan bahwa "ciri-ciri orang yang mempunyai dan menghayati etos kerja akan nampak dalam sikap dan tingkah lakunya yang dilandaskan pada suatu keyakinan yang sangat mendalam bahwa kerja itu merupakan ibadah, suatu panggilan, dan amanah. Sikap dan tingkah laku tersebut, di antaranya: (a) memiliki jiwa kepemimpinan, (b) selalu berhitung, (c) menghargai waktu, (d) tidak pernah merasa puas berbuat kebaikan (positive improvements), (e) hidup hemat dan efisien, (f) memiliki jiwa wiraswasta, (g) memiliki instink bertanding dan bersaing, (h) keinginan untuk mandiri, (i) haus untuk memiliki sifat keilmuan, (j) berwawasan makro, (k) memperhatikan kesehatan dan gizi, (l) ulet dan pantang menyerah, dan (m) berorientasi pada produktivitas". Sementara itu Cherrington seperti dikutip oleh Henry 
Ananta (1994:17) mendeskripsikan ciri-ciri orang yang memiliki etos kerja, yaitu : '(a) ada usaha keras sebagai kewajiban moral dan religius bagi setiap orang untuk mengisi hidupnya; (b) menghargai waktu kerja; (c) bertanggung jawab dalam melakukan pekerjaan; (d) menginginkan produktivitas tinggi; (c) merasa bangga terhadap profesi dan lembaganya; (I) loyal terhadap profesi dan lembaganya; (g) selalu berpartisipasi; dan (h) bersifat jujur'.

Menurut Hasibuan (2013:193-198), etos kerja guru adalah seperangkat perilaku positif guru yang berakar pada keyakinan fundamental yang disertai komitmen total pada paradigma kerja yang integral. Etos kerja adalah perasaan, sikap, dan perilaku individu mengidentifikasikan dirinya sebagai bagian dari organisasi, terlibat dalam proses kegiatan dan loyal terhadap organisasi dalam mencapai tujuan organisasi yang meliputi: 1) Dedikasi, 2) Komitmen kerja, 3) Kedisiplinan, 4) Prestasi kerja, 5) Loyalitas. Etos kerja merupakan pendukung bagi kesuksesan pencapaian tujuan organisasi. Artinya, etos kerja merupakan bagian penting dalam operasional pendidikan.

Menurut Winardi (2005:45) perilaku organisasi pada hakekatnya terdiri dan tiga mazhab klasik teori behavioral, dimana ketiga aliran ini, semuanya berorientasi pada produktivitas, efisiensi, dan efektivitas yang dikembangkan oleh tiga ahli organisasi, yaitu: (1) Scientific management olch F. Winslow Taylor atau lebih dikenal dengan Taylorism oleh para penganutnya. (2) Teori birokrasi oleh Max Weber. (3) Administrative management oleh Henri Fayol

Makmun Muchlas

(2005:2)

mengatakan bahwa perilaku organisasi diperlukan dalam manajemen modern sekarang ini karena sangat penting untuk memenangkan kompetisi lokal, nasional, dan global. Para customer saat ini menuntut lebih banyak dari apa yang diminta customer pada dekade lalu. Muchlas (2005:12) menyatakan bahwa perilaku organisasi mempelajari apa saja yang dikerjakan oleh orang-orang dalam organisasi dan bagaimana perilaku atau tindakan itu bisa mempengaruhi penampilan organisasi.

Muchlas (2005:12) mengatakan babwa perilaku organisasi meliputi topik-topik tentang motivasi, perilaku kepernimpinan dan kewenangan, komunikasi antar manusia, struktur dan proses kelompok, proses belajar, pengembangan sikap dan persepsi, prosesproses perubahan, konflik desain kerja dan stres ditempat kerja.

Nimran (2005:15-19) mengatakan bahwa yang menjadi landasan utama, bagi perilaku organisasi adalah perilaku individu dan perilaku kelompok. Perbedaan individual menjadikan organisasi menjadi sistem yang sangat kompleks. Dalam studi perilaku organisasi, perilaku individu dan perilaku kelompok menjadi faktor yang utama dalam mencari setting terbaik produktivitas.

Menurut Linton, budaya merupakan konfigurasi dari tingkah laku yang dipelajari dan hasil tingkah laku yang unsur - unsurnya digunakan bersama dan ditularkan oleh warga masyarakat (Kistanto, 2015). Menurut Fremont \& Rosenzweig, (2005:952) dalam kaitannya dengan organisasi, budaya merupakan perangkat nilai, kepercayaan, dan pemahaman pentingnya sama-sama dimiliki oleh para anggotanya. Budaya memberikan pola tentang cara berpikir merasa dan menanggapi, yang menuntun para anggota organisasi dalam mengambil keputusan dan dalam kegiatan-kegiatan organisasi lainnya. Organisasi yang sukses memiliki budaya kuat yang dapat menarik, memelihara, dan menghargai orang yang berhasil melaksanakan perannya dan mencapai sasaran.

Robbins (2005:247) mengemukakan bahwa budaya organisasi merupakan sistem makna bersama yang dianut oleh anggotaanggota yang membedakan organisasi itu dari organisasi-organisasi lain. Pendapat ini sejalan dengan batasan budaya organisasi yang dikemukakan oleh Mondy, Sharplin, dan Premeux (2005:450) yang menyatakan bahwa budaya organisasi merupakan "The system of shared values, beliefs, and habbits within an organization that interacts with the formal structure to produce behaviour norms." (Suatu sistem berbagi atas nilai, keyakinan, dan kebiasaan di dalam suatu organisasi yang sesuai dengan struktur formal untuk menghasilkan norma-norma perilaku).

Selain itu juga, Fred Luthans (2006:50) mendefinisikan budaya organisasi sebagai pola asumsi yang ditemukan dan dikembangkan oleh kelompok yang 
mencakup masalah adaptasi dengan pihak luar dan integrasi yang telah berjalan dengan cukup baik dan reliabel untuk diajarkan kepada para anggota baru sebagai tata cara berperilaku, berpikir dan bersikap terhadap permasalahan itu. Robbins mengemukakan pendapat bahwa Budaya organisasi merupakan falsafah, ideologi, nilai-nilai, anggapan, keyakinan, harapan, sikap dan norma-norma yang dimiliki secara bersama serta mengikat dalam suatu komunitas tertentu (Hormati, 2016).

Definisi di atas menjelaskan bahwa budaya organisasi sebagai suatu pola asumsi dasar, penciptaan, penemuan atau pengembangan sebagai hasil dan pembelajaran kelompok ketika mengatasi masalah penyesuaian eksternal dan integrasi internal, yang telah dikerjakan dengan cukup baik untuk menjadikan pertimbangan yang bernilai atau sah dan oleh karena itu harus dipelajari oleh anggota baru sebagai jalan terbaik untuk menerima, berpikir dan merasa berhubungan dengan masalah-masalah itu.

Sementara itu, Fred Luthan (2006:52) mengetengahkan enam karakteristik penting dari budaya organisasi, yaitu: (1) obeserved behavioral regularities; yakni keberaturan cara bertindak dari para anggota yang tampak teramati. Ketika anggota organisasi berinteraksi dengan anggota lainnya, mereka mungkin menggunakan bahasa umum, istilah, atau ritual tertentu; (2) norms; yakni berbagai standar perilaku yang ada, termasuk di dalamnya tentang pedoman sejauh mana suatu pekerjaan harus dilakukan; (3) dominant values; yaitu adanya nilai-nilai inti yang dianut bersama oleh seluruh anggota organisasi, misalnya tentang kualitas produk yang tinggi, absensi yang rendah atau efisiensi yang tinggi; (4) philosophy; yakni adanya kebijakan-kebijakan yang berkenaan dengan keyakinan organisasi dalam memperlakukan pelanggan dan karyawan; (5) rules; yaitu adanya pedoman yang ketat, dikaitkan dengan kemajuan organisasi (6) organization climate; merupakan perasaan keseluruhan (an overall "feeling") yang tergambarkan dan disampaikan melalui kondisi tata ruang, cara berinteraksi para anggota organisasi dan cara anggota organisasi memperlakukan dirinya, pelanggan atau orang lain.
Budaya organisasi terbentuk dari rangkaian interaksi individu-individu di dalam organisasi berkaitan dengan perbuatan, kreativitas, menggerakkan, mengontrol dan mengevaluasi struktur dan kinerja organisasi sesuai dengan peran dan fungsinya secara terus-menerus sehingga pada akhirnya akan membentuk suatu pola budaya tertentu yang unik dan berbeda antara satu organisasi dengan organisasi lainnya. Dengan demikian, budaya organisasi mengarah pada pengakuan para anggota organisasi terhadap suatu sistem makna bersama yang berbeda antara satu organisasi dengan organisasi lainnya.

Robbins (2005:721) menyebutkan ada tujuh karakteristik primer yang merupakan hakikat dari budaya organisasi, yaitu: (1) Inovasi dan pengambilan resiko: sejauh mana para karyawan didorong agar inovatif dan mengambil resiko. (2) Perhatian terhadap detail. Sejauh mana para karyawan diharapkan memperlihatkan presisi (kecermatan), analisis, dan perhatian terhadap detail. (3) Orientasi hasil: Sejauh mana manajemen memusatkan perhatian pada hasil dan bukannya pada teknik dan proses yang digunakan untuk mencapai hasil itu. (4) Orientasi orang: Sejauh mana keputusan manajemen memperhitungkan dampak hasil pada orang-orang di dalam organisasi itu. (5) Orientasi tim: sejauh mana kegiatan kerja diorganisasikan berdasarkan kelompok, bukannya berdasarkan individu. (6) Keagresifan: sejauh mana orang-orang itu agresif dan kompeten dan bukannya santaisantai. (7) Kemantapan: Sejauh mana kegiatan organisasi menekankan dipertahankannya status quo bukannya pertumbuhan.

Ketujuh karakteristik tersebut berada pada kontinum dari rendah ke tinggi. Maka penilaian terhadap organisasi dengan berdasarkan pada tujuh karakteristik tersebut di atas dan memperoleh gambaran menyeluruh budaya suatu organisasi. Karakteristik-karakteristik tersebut bukan untuk menilai apakah budaya suatu organisasi itu rendah maupun tinggi. Dalam banyak organisasi, salah satu karakter budaya tersebut kadang muncul di atas yang lain dan biasanya membentuk kepribadian organisasi dan cara kerja anggota organisasi.

Sebagai suatu organisasi, sekolah memiliki budaya tersediri yang terbentuk dan 
terpengaruh oleh nilai, persepsi, kebiasaan, kebijakan, dan perilaku orang-orang di dalamnya. Dengan demikian maka sekolah memiliki ciri khas yang membedakannya dengan organisasi lain yaitu proses pembelajaran. Organisasi sekolah harus mampu menampilkan dan menunjukkan fungsi yang sesuai dengan kekhasan yang dimilikinya tersebut.

Budaya sekolah merupakan karakter khas yang dimiliki sekolah sesuai dengan norma, nilai, dan kebiasaan di sekolah itu dalam penyelenggaraan pendidikan untuk menumbuhkembangkan peserta didik menjadi manusia-manusia berkualitas. Perbedaan budaya setiap sekolah adalah dalam bentuk operasional dan kebijakan sesuai dengan situasi dan kondisi yang ada di sekitar sekolah itu, akan tetapi esensi budaya setiap sekolah tetaplah sama. Jadi yang membedakan antara sekolah yang satu dengan sekolah lainnya adalah situasi dan kondisi masing-masing sekolah.

Pembentukan budaya pada suatu organisasi merupakan tugas utama seorang pemimpin, lemah atau kuatnya budaya suatu organisasi sangat tergantung pada sejauh mana pemimpin organisasi tersebut mampu menanamkan nilai-nilai luhur organisasi yang dipimpinnya kepada para anggota. Dalam konteks budaya sekoalah, kepala sekolahlah yang memegang peranan sentral di dalam menciptakan, mengomunikasikan, dan mengendalikan nilai-nilai luhur sehingga terbentuknya budaya sekolah dalam rangka tujuan sekolah diinginkan.

Nillai, keyakinan, sikap, dan perilaku adalah komponen-komponen budaya yang esensial dalam membentuk karakter sekolah. Harus disadari bahwa budaya sekolah merupakan asumsi dasar dan kepercayaan

\section{METODE PENELITIAN}

Penelitian ini dilaksanakan pada sekolah menengah pertama (SMP) Negeri di Kecamatan Kramatmulya Kabupaten Kuningan. Metode yang digunakan adalah metode survey di mana penulis terjun langsung ke tataran empirik untuk menyebarkan angket terhadap 62 responden sebagai teknik pengumpulan data, selain studi dokumentasi, observasi dan wawancara yang dapat membuat sekolah memiliki citra yang membangun. Dewey (2005:176) mengungkapkan bahwa budaya organisasi (sekolah) didefinisikan dalam terminologi orientasi bersama yang menyatukan unit menjadi bersama dan menunjukkan identitas khusus.

Budaya adalah nilai-nilai dasar sekolah yang merupakan harapan-harapan atas perilaku yang diinginkan yang secara umum mencakup nilai-nilai tentang hal-hal yang layak dan bagaimana melakukannya, serta asumsi-asumsi atas apa yang sudah dilakukan di waktu lampau. Budaya dapat diartikan sebagai perekat dan ciri khas organisasi yang akan membedakan antara satu sekolah dengan sekolah lainnya yang ditularkan kepada setiap personil baru sekolah.

Berdasarkan pemaparan diatas maka dapat disimpulkan bahwa budaya organisasi dalam penelitian ini merupakan sistem makna bersama yang dianut oleh kepala sekolah, para guru, para siswa, dan semua personil sekolah yang membedakan sekolah itu dari sekolah-sekolah lainnya. Bertumpu pada berbagai konsep dan pengertian perilaku organisasi di atas dapat disarikan bahwa perilaku organisasi adalah interaksi antar anggota organisasi dan interaksi antara anggota organisasi dengan pimpinan organisasi baik dalam bentuk komunikasi, perilaku kepemimpinan dan proses kelompok. Dengan dimensi: (1) Komunikasi; (2) Perilaku dan kewenangan pimpinan; (3) Motivasi; (4) Struktur dan proses kelompok; (5) Perubahan dan pengembangan (Muchlas, 2005).

kepada pihak terkait. Pendekatan yang digunakan adalah pendekatan kuantitatif dengan analisis statistik deskriptif. Teknik pengolahan dan analisis yang digunakan adalah regresi. Aspek konseptual yang berkaitan dengan permasalahan yang diteliti. diambil intisarinya ke dalam operasionalisasi variabel guna memudahkan dalam pengumpulan data. Variabel dan dimensi dimaksud disusun pada sebuah tabel berikut: 
Tabel 1: Kisi-kisi Instrumen Penelitian Variabel Perilaku Organisasi

\begin{tabular}{|c|c|}
\hline Dimensi & Indikator \\
\hline 1) Komunikasi & $\begin{array}{l}\text { - } \text { Memiliki karisma } \\
\text { - Terbuka terhadap kritik } \\
\text { - Terbuka terhadap karyawan } \\
\text { - Menjadi solusi terhadap masalah } \\
\text { - Selalu mendorong bawahan } \\
\end{array}$ \\
\hline 2) Perilaku dan kewenangan pimpinan & $\begin{array}{ll}\text { - Kesantunan } \\
\text { - Apresiasi } \\
\text { - Kepercayaan } \\
\text { - Keterbukaan }\end{array}$ \\
\hline 3) Motivaso & $\begin{array}{ll}\text { - } & \text { Pujian } \\
\text { - } & \text { Penghargaan }\end{array}$ \\
\hline 4) Struktur dan proses kelompok & $\begin{array}{l}\text { - Melembaga } \\
\text { - Kebersamaan }\end{array}$ \\
\hline 5) Perubahan dan pengembangan & $\begin{array}{l}\text { - Kesiapan } \\
\text { - Dukungan } \\
\text { - Kesertaan pada forum ilmiah }\end{array}$ \\
\hline
\end{tabular}

Sumber: Muchlas (2005)

Tabel 2: Kisi-kisi Instrumen Penelitian Variabel Budaya Organisasi

\begin{tabular}{|c|c|}
\hline Dimensi & Indikator \\
\hline 1) Inovasi dan pengambilan resiko & $\begin{array}{l}\text { - Tersedianya peluang untuk meningkatkan kreativitas, } \\
\text { serta mau mengambil resiko } \\
\text { - Dukungan sekolah kepada guru yang mencoba ide } \\
\text { baru dalam pemecahan masalah }\end{array}$ \\
\hline 2) Perhatian terhadap kerincian & $\begin{array}{l}\text { - Kewenangan yang diberikan sekolah kepada guru } \\
\text { untuk memecahkan masalah } \\
\text { - Kesesuaian pendidikan, keahlian dan kemampuan } \\
\text { yang dimiliki guru dengan tugas dan beban kerjanya }\end{array}$ \\
\hline 3) Orientasi pada hasil & $\begin{array}{l}\text { - Tugas-tugas rutin ditetapkan oleh organisasi } \\
\text { - Peluang yang diberikan sekolah kepada guru dalam } \\
\text { mengembangkan pengetahuan dan kemampuannya } \\
\text { - Kejelasan standar keberhasilan tugas dan } \\
\text { penyampaian standar tersebut dengan jelas } \\
\text { - Kesempatan untuk mengembangkan segala } \\
\text { kompetensi yang dimiliki }\end{array}$ \\
\hline 4) Orientasi pada individu & $\begin{array}{l}\text { - Peluang yang diberikan untuk mengikuti } \\
\text { diklat/penataran yang relevan, serta melanjutkan studi } \\
\text { - Peluang untuk menyampaikan gagasan/saran dan } \\
\text { kritik } \\
\text { - Pemberian penghargaan terhadap keberhasilan } \\
\text { pelaksanaan tugas } \\
\text { - Pemberdayaan guru berdasarkan potensi yang } \\
\text { dimiliki } \\
\text { - Kesempatan untuk menyesuaikan diri dengan nilai- } \\
\text { nilai baru yang dianggap paling sesuai }\end{array}$ \\
\hline 5) Orientasi pada Tim & $\begin{array}{l}\text { - Interaksi dan kerjasama dalam melaksanakan tugas } \\
\text { dalam rangka pencapaian tujuan bersama } \\
\text { - Tim kerja bertanggung jawab dalam melaksanakan } \\
\text { program kerja sesuai dengan tujuan yang telah } \\
\text { ditetapkan } \\
\text { - Komunikasi dan kepercayaan antara sesama rekan } \\
\text { kerja untuk perubahan }\end{array}$ \\
\hline 6) Keagresifan & $\begin{array}{l}\text { - Situasi kerja kondusif yang mendorong para guru } \\
\text { untuk bekerja keras } \\
\text { - Tantangan pekerjaan yang diciptakan sekolah untuk } \\
\text { guru }\end{array}$ \\
\hline 7) Kemantapan & $\begin{array}{l}\text { - Konsistensi dalam melaksanakan tugas dan tanggung } \\
\text { jawab } \\
\text { - Kesamaan visi dalam melaksanakan tugas dan } \\
\text { tanggung jawab }\end{array}$ \\
\hline
\end{tabular}

Sumber: Robbins (2005) 
Tabel 3: Kisi-kisi Instrumen Penelitian Variabel Etos Kerja

\begin{tabular}{|c|c|}
\hline Dimensi & Indikator \\
\hline 1) Dedikasi & $\begin{array}{l}\text { - Kepribadian } \\
\text { - Menghargai }\end{array}$ \\
\hline 2) Komitmen kerja & $\begin{array}{l}\text { - Ulet } \\
\text { - Pengabdian }\end{array}$ \\
\hline 3) Kedisiplinan & $\begin{array}{l}\text { - Tata aturan } \\
\text { - Bekerja keras } \\
\text { - Berkelanjutan }\end{array}$ \\
\hline 4) Prestasi kerja & $\begin{array}{l}\text { - Melaksanakan tugas } \\
\text { - Bekerjasama }\end{array}$ \\
\hline 5) Loyalitas & $\begin{array}{l}\text { - Adaptasi lingkungan } \\
\text { - Memajukan organisasi }\end{array}$ \\
\hline
\end{tabular}

Sumber: Hasibuan (2013)

\section{PEMBAHASAN HASIL PENELITIAN}

Untuk mengetahui besaran pengaruh perilaku organisasi $\left(\mathrm{X}_{1}\right)$ secara individual (parsial) terhadap etos kerja guru (Y) dapat dilihat dari nilai $\mathrm{t}$ pada tabel Coefficients dibawah ini dengan kriteria pengujian jika tingkat signifikansi lebih kecil dari 0,05, maka hipotesis diterima. Adapun hasil pengujian hipotesis tersebut adalah sebagai berikut:

Tabel 4: Uji Hipotesis (t) Variabel $X_{1}$ terhadap $Y$

\begin{tabular}{|c|c|c|c|c|c|c|}
\hline & \multirow[b]{2}{*}{ Model } & \multicolumn{2}{|c|}{$\begin{array}{c}\text { Unstandardized } \\
\text { Coefficients }\end{array}$} & \multirow{2}{*}{$\begin{array}{c}\begin{array}{c}\text { Standardized } \\
\text { Coefficients }\end{array} \\
\text { Beta }\end{array}$} & \multirow[b]{2}{*}{$\mathrm{t}$} & \multirow[b]{2}{*}{ Sig. } \\
\hline & & $\mathrm{B}$ & Std. Error & & & \\
\hline \multirow[t]{2}{*}{1} & (Constant) & 28,394 & 10,233 & & 2,775 &, 007 \\
\hline & Perilaku_Organisasi_X ${ }_{1}$ & ,953 &, 175 & ,576 & 5,458 &, 000 \\
\hline
\end{tabular}

a. Dependent Variable: Etos_Kerja_Guru_Y

Berdasarkan tabel hasil uji $t$ diperoleh bahwa nilai $t_{\text {hitung }}$ variabel perilaku organisasi $\left(\mathrm{X}_{1}\right)$ memiliki nilai sebesar $p$-value $0,000<0,05$ artinya berdistribusi signifikan. Hal tersebut berarti perilaku organisasi $\left(\mathrm{X}_{1}\right)$ secara parsial berpengaruh terhadap etos kerja guru (Y). Persamaan regresi $\mathrm{y}=\mathrm{a} \mathrm{bx}_{1}$ dari hasil perhitungan diperoleh $\mathrm{y}=28,394$ $+0,953 X_{1}$. Konstanta sebesar 28,394 menyatakan bahwa jika ada kenaikan nilai dari variabel perilaku organisasi $\left(\mathrm{X}_{1}\right)$, maka etos kerja guru $(\mathrm{Y})$ adalah 28,394. Koefesien regresi sebesar 0,953 menyatakan bahwa setiap perubahan satu skor atau nilai perilaku organisasi akan memberikan skor 0,953. Dasar pengambilan keputusan yaitu dengan membandingkan $\mathrm{F}$ hitung dengan nilai $\mathrm{F}$ tabel sebagai berikut: jika nilai signifikansi < 0,05, maka Ho ditolak artinya koefesien regresi signifikan, dan sebaliknya.

Tabel 5: Signifikansi Pengaruh Variabel $X_{1}$ terhadap $Y$

\begin{tabular}{|ll|r|r|r|r|c|}
\hline & Model & Sum of Squares & \multicolumn{1}{c|}{ df } & Mean Square & F & Sig. \\
\hline 1 & Regression & 1811,763 & 1 & 1811,763 & 29,789 &, $000^{\mathrm{b}}$ \\
& Residual & 3649,221 & 60 & 60,820 & & \\
Total & 5460,984 & 61 & & & \\
\hline
\end{tabular}

a. Dependent Variable: Etos_Kerja_Guru_Y

b. Predictors: (Constant), Perilaku_Organisasi_X $X_{1}$ 
Berdasarkan tabel hasil uji anova atau $\mathrm{F}$ test didapat $\mathrm{F}_{\text {hitung }}$ sebesar 29,789 dan nilai signifikansi $0,000<0,05$. Dengan demikian $\mathrm{H}_{\mathrm{o}}$ ditolak artinya pengaruh perilaku organisasi terhadap etos kerja guru.
Selanjutnya untuk mengetahui besaran pengaruh perilaku organisasi terhadap etos kerja guru dapat dilihat dari hasil perhitungan koefesien determinasi pada tabel dibawah ini:

Tabel 6: Besaran Pengaruh Variabel $X_{1}$ Terhadap $Y$

\begin{tabular}{|c|r|r|r|r|}
\hline Model & R & R Square & $\begin{array}{c}\text { Adjusted R } \\
\text { Square }\end{array}$ & $\begin{array}{c}\text { Std. Error of the } \\
\text { Estimate }\end{array}$ \\
\hline 1 &, $576^{\mathrm{a}}$ &, 332 &, 321 & 7,799 \\
\hline
\end{tabular}

a. Predictors: (Constant), Perilaku_Organisasi_X

Dari tabel di atas terlihat bahwa $R$ Square sebesar 0,332, hal ini berarti bahwa $33,2 \%$ etos kerja guru dipengaruhi oleh variabel perilaku organisasi, sedangkan sisanya $66,8 \%$ dipengaruhi oleh faktor lain yang tidak diteliti

Untuk mengetahui besaran pengaruh budaya organisasi $\left(\mathrm{X}_{2}\right)$ secara individual (parsial) terhadap etos kerja guru (Y) dapat dilihat dari nilai $\mathrm{t}$ pada tabel Coefficients dibawah ini dengan kriteria pengujian jika tingkat signifikansi lebih kecil dari 0,05, maka hipotesis diterima. Adapun hasil pengujian hipotesis tersebut adalah sebagai berikut:

Tabel 7: Uji Hipotesis (t) Variabel $\mathbf{X}_{2}$ terhadap $\mathbf{Y}$

\begin{tabular}{|c|c|c|c|c|c|}
\hline \multirow[b]{2}{*}{ Model } & \multicolumn{2}{|c|}{$\begin{array}{l}\text { Unstandardized } \\
\text { Coefficients }\end{array}$} & $\begin{array}{l}\text { Standardized } \\
\text { Coefficients }\end{array}$ & & \\
\hline & $\mathrm{B}$ & Std. Error & Beta & $\mathrm{t}$ & Sig. \\
\hline $\begin{array}{ll}1 & \text { (Constant) } \\
& \text { Budaya_Organisasi_X }\end{array}$ & $\begin{array}{r}44,802 \\
, 529\end{array}$ & $\begin{array}{r}9,411 \\
, 126\end{array}$ & ,476 & $\begin{array}{l}4,761 \\
4,190\end{array}$ & $\begin{array}{l}, 000 \\
, 000\end{array}$ \\
\hline
\end{tabular}

a. Dependent Variable: Etos_Kerja_Guru_Y

Berdasarkan tabel hasil uji $\mathrm{t}$ diperoleh bahwa nilai $t_{\text {hitung }}$ variabel budaya organisasi $\left(\mathrm{X}_{2}\right)$ memiliki nilai sebesar $p$-value $0,000<0,05$ artinya signifikan. Dengan demikian budaya organisasi $\left(\mathrm{X}_{2}\right)$ secara parsial berpengaruh terhadap etos kerja guru (Y). Persamaan regresi $\mathrm{y}=\mathrm{a} \mathrm{bx}_{2}$ dari hasil perhitungan diperoleh $\mathrm{y}=44,802+0,529 \mathrm{X}_{2}$. Konstanta sebesar 44,802 menyatakan bahwa jika ada kenaikan nilai dari variabel budaya organisasi $\left(\mathrm{X}_{2}\right)$, maka etos kerja guru $(\mathrm{Y})$ adalah 44,802. Koefesien regresi sebesar 0,529 menyatakan bahwa setiap perubahan satu skor atau nilai budaya organisasi akan memberikan skor 0,529.

Dasar pengambilan keputusan, yaitu dengan membandingkan nilai hitung $F$ dengan nilai tabel $\mathrm{F}$ sebagai berikut: Jika nilai hitung $\mathrm{F}$ lebih besar dari nilai tabel $\mathrm{F}$, maka $\mathrm{H}_{0}$ ditolak artinya koefisien regresi signifikan, dan sebaliknya.

Tabel 8: Signifikansi Pengaruh Variabel $X_{2}$ terhadap $Y$

\begin{tabular}{|ll|r|r|r|r|r|}
\hline & Model & Sum of Squares & Df & Mean Square & F & Sig. \\
\hline 1 & Regression & 1236,349 & 1 & 1236,349 & 17,559 & \multirow{2}{*}{, $000^{\mathrm{b}}$} \\
& Residual & 4224,635 & 60 & 70,411 & & \\
Total & 5460,984 & 61 & & & \\
\hline
\end{tabular}

a. Dependent Variable: Etos_Kerja_Guru_Y

b. Predictors: (Constant), Bud._Organisasi_X 
Berdasarkan tabel hasil uji anova atau $F$ test didapat $F_{\text {hitung }}$ sebesar 17,559 dan signifikansi $0,000<0,05$ sehingga $\mathrm{H}_{\mathrm{o}}$ ditolak artinya pengaruh budaya organisasi terhadap etos kerja guru. Selanjutnya untuk mengetahui besaran pengaruh budaya organisasi terhadap etos kerja guru dapat dilihat dari hasil perhitungan koefesien determinasi pada tabel dibawah ini:

Tabel 9: Besaran Pengaruh Variabel $X_{2}$ terhadap $Y$

\begin{tabular}{|c|r|r|r|r|}
\hline Model & R & R Square & $\begin{array}{c}\text { Adjusted R } \\
\text { Square }\end{array}$ & $\begin{array}{c}\text { Std. Error of the } \\
\text { Estimate }\end{array}$ \\
\hline 1 &, $476^{\mathrm{a}}$ &, 226 &, 214 & 8,391 \\
\hline
\end{tabular}

a. Predictors: (Constant), Budaya_Organisasi_X

Dari tabel di atas terlihat bahwa $R$ Square sebesar 0,226, hal ini berarti bahwa $22,6 \%$ etos kerja guru dipengaruhi oleh variabel budaya organisasi, sedangkan sisanya $77,4 \%$ dipengaruhi oleh faktor lain yang tidak diteliti.

Untuk mengetahui besaran pengaruh perilaku organisasi $\left(\mathrm{X}_{1}\right)$ dan budaya organisasi secara bersama-sama (simultan) terhadap etos kerja guru (Y) dapat dilihat dari nilai t pada tabel Coefficients dibawah ini dengan kriteria pengujian jika tingkat signifikansi lebih kecil dari 0,05, maka hipotesis diterima. Adapun hasil pengujian hipotesis tersebut adalah sebagai berikut:

Tabel 10: Uji Hipotesis (t) Variabel $X_{1}$ dan $X_{2}$ terhadap $Y$

\begin{tabular}{|c|c|c|c|c|c|c|}
\hline \multirow{2}{*}{\multicolumn{2}{|c|}{ Model }} & \multicolumn{2}{|c|}{$\begin{array}{c}\text { Unstandardized } \\
\text { Coefficients }\end{array}$} & \multirow{2}{*}{$\begin{array}{c}\begin{array}{c}\text { Standardize } \\
\mathrm{d} \\
\text { Coefficients }\end{array} \\
\text { Beta } \\
\end{array}$} & \multirow[b]{2}{*}{$\mathrm{t}$} & \multirow[b]{2}{*}{ Sig. } \\
\hline & & $\mathrm{B}$ & Std. Error & & & \\
\hline \multirow[t]{3}{*}{1} & (Constant) & 26,742 & 10,446 & & 2,560 & ,013 \\
\hline & Perilaku_Organisasi_X1 & ,802 &, 252 & ,484 & 3,181 &, 002 \\
\hline & Budaya_Organisasi_X2 &, 142 & 169 &, 128 &, 838 &, 405 \\
\hline
\end{tabular}

a. Dependent Variable: Etos_Kerja_Guru_Y

Berdasarkan tabel hasil uji t diperoleh bahwa nilai thitung variabel perilaku organisasi $\left(\mathrm{X}_{1}\right)$ dan budaya organisasi $\left(\mathrm{X}_{2}\right)$ secara bersama-sama (simultan) memiliki nilai sebesar $p$-value $0,000<0,05$ artinya signifikan. Dengan demikian perilaku

organisasi $\left(\mathrm{X}_{1}\right)$ dan budaya organisasi $\left(\mathrm{X}_{2}\right)$ secara bersama-sama (simultan) berpengaruh terhadap etos kerja guru (Y). Untuk mengetahui persamaan regresi dapat dilihat dari tabel di atas. Berdasarkan tabel tersebut menunjukkan persamaan regresi liniar ganda: $\mathrm{Y}=26,742+0,802 \mathrm{X}_{1}+0,142 \mathrm{X}_{2}$. Persamaan tersebut menyatakan bahwa setiap penambahan $\mathrm{X}_{1}$ dan $\mathrm{X}_{2}$ sebesar 1 maka akan meningkatkan $\mathrm{Y}$ sebesar 0,802 dan 0,142 , artinya setiap peningkatan perilaku organisasi dan budaya organisasi sebesar 1, akan meningkatkan etos kerja guru sebesar 0,802 dan 0,142 .

Dasar pengambilan keputusan yaitu dengan membandingkan $\mathrm{F}$ hitung dengan nilai $F$ tabel sebagai berikut: Jika nilai signifikansi < 0,05, maka Ho ditolak artinya koefisien regresi signifikan, dan sebaliknya. 
Tabel 11: Signifikansi Pengaruh Variabel $X_{1}$ dan $X_{2}$ terhadap $Y$

\begin{tabular}{|ll|r|r|r|r|l|}
\hline & Model & Sum of Squares & \multicolumn{1}{c|}{ df } & Mean Square & F & Sig. \\
\hline 1 & Regression & 1854,714 & 2 & 927,357 & 15,172 &, $000^{\mathrm{b}}$ \\
& Residual & 3606,270 & 59 & 61,123 & & \\
Total & 5460,984 & 61 & & & \\
\hline
\end{tabular}

a. Dependent Variable: Etos_Kerja_Guru_Y

b. Predictors: (Constant), Budaya_Organisasi_X $X_{2}$, Perilaku_Organisasi_X ${ }_{1}$

Berdasarkan tabel hasil uji anova atau $\mathrm{F}$ test didapat $\mathrm{F}_{\text {hitung }}$ sebesar 15,172 dan signifikansi $0,000<0,05$ sehingga $\mathrm{H}_{\mathrm{o}}$ ditolak artinya pengaruh perilaku organisasi dan budaya organisasi secara simultan terhadap etos kerja guru. Selanjutnya untuk mengetahui besaran pengaruh perilaku organisasi dan budaya organisasi secara bersama-sama (simultan) terhadap etos kerja guru dapat dilihat dari hasil perhitungan koefesien determinasi pada tabel dibawah ini:

Tabel 12: Besaran Pengaruh Variabel $X_{1}$ dan $X_{2}$ terhadap $Y$

\begin{tabular}{|c|r|r|r|r|}
\hline Model & R & R Square & $\begin{array}{c}\text { Adjusted R } \\
\text { Square }\end{array}$ & $\begin{array}{c}\text { Std. Error of the } \\
\text { Estimate }\end{array}$ \\
\hline 1 &, $583^{\mathrm{a}}$ &, 340 &, 317 & 7,818 \\
\hline
\end{tabular}

a. Predictors: (Constant), Budaya_Organisasi_ $X_{2}$,

Perilaku_Organisasi_X

Dari tabel di atas terlihat bahwa $R$ Square sebesar 0,340 , hal ini berarti bahwa $34 \%$ etos kerja guru dipengaruhi oleh variabel perilaku organisasi dan budaya organisasi secara bersama-sama (simultan), sedangkan sisanya $66 \%$ dipengaruhi faktor lain yang tidak diteliti.

\section{PEMBAHASAN}

Permasalahan pertama yang ingin dijawab dalam penelitian ini adalah adakah pengaruh perilaku organisasi terhadap etos kerja guru. Secara empirik, hasil penelitian ini menginformasikan, bahwa terdapat pengaruh yang signifikan perilaku organisasi terhadap etos kerja guru. Besarnya pengaruh perilaku organisasi terhadap etos kerja guru ditunjukkan oleh hasil penelitian bahwa perilaku organisasi yang terdiri dari dimensi: (1) komunikasi; (2) perilaku dan kewenangan pimpinan; (3) motivasi; (4) struktur dan proses kelompok; (5) perubahan dan pengembangan. (Muchlas, 2005), membawa implikasi yang signifikan terhadap etos kerja guru yang meliputi dimensi: (1) dedikasi; (2) komitmen kerja; (3) kedisiplinan; (4) prestasi kerja, dan loyalitas (Hasibuan, 2013).

Sesuai pendapat Muchlas (2005:2) yang mengatakan bahwa perilaku organisasi diperlukan dalam manajemen modern sekarang ini karena sangat penting untuk memenangkan kompetisi lokal, nasional, dan global. Para customer saat ini menuntut lebih banyak dari apa yang diminta customer pada dekade lalu. Namun demikian etos kerja guru ini tidak hanya dipengaruhi oleh perilaku organisasi saja, ada faktor lain (epsilon), selain budaya organisasi, yang juga berpengaruh, yang tidak dikaji dalam penelitian ini. Dengan demikian, hasil penelitian ini mengindikasikan bahwa semakin bagus perilaku organisasi yang dirasakan oleh guru, maka akan diikuti oleh semakin tingginya etos kerja guru. Hal ini dapat diterangkan oleh persamaan regresi y $=28,394+0,953 \mathrm{X}_{1}$. Dengan persamaan regresi tersebut dapat diinterpretasikan bahwa jika perilaku organisasi $\left(\mathrm{X}_{1}\right)$ dengan etos kerja guru (Y) diukur dengan instrumen yang dikembangkan dalam penelitian ini, maka setiap perubahan skor perilaku 
organisasi sebesar satu satuan dapat diestimasikan skor etos kerja guru akan berubah 0,953 satuan pada arah yang sama.

Hasil penelitian ini memberikan informasi, bahwa salah satu cara untuk meningkatkan etos kerja guru adalah dengan meningkatkan perilaku organisasi.

Permasalahan kedua, yang ingin dijawab dalam penelitian ini adalah adakah pengaruh budaya organisasi terhadap etos kerja guru. Secara empirik, hasil penelitian ini menginformasikan bahwa, terdapat pengaruh yang signifikan budaya organisasi terhadap etos kerja guru. Besarnya pengaruh budaya organisasi terhadap etos kerja guru ditunjukkan oleh hasil penelitian bahwa tingginya budaya organisasi yang terdiri dari dimensi: (1) inovasi dan pengambilan resiko; (2) perhatian terhadap kerincian (detail); (3) orientasi pada hasil; (4) orientasi pada individu; (5) orientasi pada tim; (6) keagresifan, dan (7) kemantapan (Robbins, 2005), membawa implikasi yang signifikan terhadap etos kerja guru yang meliputi dimensi: (1) dedikasi; (2) komitmen kerja; (3) kedisiplinan; (4) prestasi kerja, dan (5)loyalitas (Hasibuan, 2013).

$$
\text { Edgar Schein }
$$

mendefinisikan budaya sebagai: A pattern of shared basic assumptions that the group learned as it solved its problems of external adaptation and internal integration, that has worked well enough to be considered valid and, therefore, to be taught to new members as the correct way you perceive, think, and feel in relation to those problems. Pendapat di atas mengatakan bahwa budaya organisasi merupakan suatu pola berbagi atas asumsiasumsi dasar yang dikembangkan oleh kelompok pada saat mengadaptasi pengaruh dari luar dan mengintegrasikannya ke dalam kelompok. Di mana asumsi-asumsi dasar tersebut telah berfungsi dengan cukup baik dan dianggap valid. Sehingga asumsi-asumsi dasar tersebut dapat diajarkan kepada anggota baru sebagai cara yang benar untuk menerima, memikirkan, dan merasakan untuk penyelesaian masalah kelompok. Kata kunci dari pengertian budaya yaitu berbagi asumsi- asumsi dasar (shared basic assumptions) yang meliputi keyakinan dan nilai-nilai.

Namun demikian etos kerja ini tidak hanya dipengaruhi oleh budaya organisasi saja, ada faktor lain (epsilon), selain perilaku organisasi yang juga berpengaruh, yang tidak dikaji dalam penelitian ini. Hasil penelitian ini mengindikasikan bahwa semakin bagus kondisi budaya organisasi yang dirasakan guru, maka akan diikuti oleh semakin tingginya etos kerja guru.

Hal ini dapat diterangkan oleh persamaan regresi $\mathrm{Y}=44,802+0,529 \mathrm{X}_{2}$. Dengan persamaan regresi tersebut dapat diinterpretasikan bahwa jika budaya organisasi $\left(\mathrm{X}_{2}\right)$ dengan etos kerja guru $(\mathrm{Y})$ diukur dengan instrumen yang dikembangkan dalam penelitian ini, maka setiap perubahan skor budaya organisasi sebesar satu satuan dapat diestimasikan skor etos kerja guru akan berubah 0,529 satuan pada arah yang sama. Hasil penelitian ini memberikan informasi, bahwa salah satu cara untuk meningkatkan etos kerja guru adalah dengan meningkatkan budaya organisasi.

Permasalahan ketiga yang ingin dijawab dalam penelitian ini adalah adakah pengaruh perilaku organisasi dan budaya organisasi secara simultan terhadap etos kerja guru. Secara empirik, hasil penelitian ini menginformasikan, bahwa terdapat pengaruh yang signifikan perilaku dan budaya organisasi secara simultan terhadap etos kerja guru Besarnya pengaruh perilaku organisasi dan budaya organisasi secara simultan terhadap etos kerja ditunjukkan oleh hasil penelitian bahwa perilaku organisasi yang terdiri dari dimensi: (1) komunikasi; (2) perilaku dan kewenangan pimpinan; (3) motivasi; (4) struktur dan proses kelompok; (5) perubahan dan pengembangan. (Muchlas, 2005), serta budaya organisasi yang terdiri dari dimensi: (1) inovasi dan pengambilan resiko; (2) perhatian terhadap kerincian (detail); (3) orientasi pada hasil; (4) orientasi pada individu; (5) orientasi pada tim; (6) keagresifan, dan (7) kemantapan (Robbins, 2005), membawa implikasi yang signifikan terhadap etos kerja guru yang meliputi dimensi: (1) dedikasi; (2) komitmen kerja; 
(3) kedisiplinan; (4) prestasi kerja, dan (5) loyalitas (Hasibuan, 2013).

Secara kebermaknaan hampir senada dengan Tasmara (2001:29), bahwa ciri-ciri orang yang mempunyai dan menghayati etos kerja akan nampak dalam sikap dan tingkah lakunya yang dilandaskan pada suatu keyakinan yang sangat mendalam bahwa kerja itu merupakan ibadah, suatu panggilan, dan amanah. Sikap dan tingkah laku tersebut, di antaranya: (a) memiliki jiwa kepemimpinan, (b) selalu berhitung, (c) menghargai waktu, (d) tidak pernah merasa puas berbuat kebaikan (positive improvements), (e) hidup hemat dan efisien, (f) memiliki jiwa wiraswasta, (g) memiliki instink bertanding dan bersaing, (h) keinginan untuk mandiri, (i) haus untuk memiliki sifat keilmuan, (j) berwawasan makro, (k) memperhatikan kesehatan dan gizi, (l) ulet dan pantang menyerah, dan (m) berorientasi pada produktivitas. Sementara itu Cherrington seperti dikutip oleh Henry Ananta (1994:17) mendeskripsikan ciri-ciri orang yang memiliki etos kerja, yaitu : '(a) ada usaha keras sebagai kewajiban moral dan religius bagi setiap orang untuk mengisi hidupnya; (b) menghargai waktu kerja; (c) bertanggung jawab dalam melakukan pekerjaan; (d) menginginkan produktivitas tinggi; (c) merasa bangga terhadap profesi dan lembaganya; (I) loyal terhadap profesi dan lembaganya; (g) selalu berpartisipasi; dan (h) bersifat jujur'.

Namun demikian etos kerja guru, selain dipengaruhi oleh kedua variabel di atas, ada faktor lain (epsilon), yang juga berpengaruh, yang tidak dikaji dalam penelitian ini. Dengan demikian, hasil penelitian ini mengindikasikan bahwa semakin bagus kondisi perilaku dan budaya organisasi secara simultan yang dirasakan oleh guru, maka akan diikuti oleh semakin tingginya etos kerja guru. Hal ini dapat diterangkan oleh persamaan regresi $\mathrm{Y}=$ $26,742+0,802 \mathrm{X}_{1}+0,142 \mathrm{X}_{2}$. Dengan persamaan regresi tersebut dapat diinterpretasikan bahwa jika perilaku organisasi $\left(\mathrm{X}_{1}\right)$, dan budaya organisasi $\left(\mathrm{X}_{2}\right)$ dan etos kerja guru (Y) diukur dengan instrumen yang dikembangkan dalam penelitian ini, maka setiap perubahan skor perilaku organisasi, dan budaya organisasi secara simultan sebesar satu satuan dapat diestimasikan skor etos kerja guru akan berubah 0,802 dan 0,142 satuan pada arah yang sama. Hasil penelitian ini memberikan informasi, bahwa salah satu cara untuk meningkatkan etos kerja guru adalah dengan meningkatkan perilaku organisasi dan budaya organisasi.

\section{KESIMPULAN}

Pada bagian akhir tulisan ini penulis menyampaikan kesimpulan bahwa. Pertama, terdapat pengaruh yang positif dan signifikan perilaku organisasi terhadap etos kerja guru. Besarnya pengaruh perilaku organisasi terhadap etos kerja guru ditunjukkan oleh hasil penelitian bahwa perilaku organisasi yang dirasakan oleh guru membawa implikasi yang signifikan terhadap etos kerja. Kedua, terdapat pengaruh yang positif dan signifikan budaya organisasi terhadap etos kerja guru. Besarnya pengaruh budaya organisasi terhadap etos kerja guru ditunjukkan oleh hasil penelitian bahwa budaya organisasi yang dirasakan oleh guru membawa implikasi yang signifikan terhadap etos kerja. Ketiga, terdapat pengaruh yang positif dan signifikan perilaku dan budaya organisasi secara bersama-sama (simultan) terhadap etos kerja guru. Besarnya pengaruh perilaku dan budaya organisasi secara bersama-sama (simultan) terhadap etos kerja guru ditunjukkan oleh hasil penelitian bahwa perilaku dan budaya organisasi yang dirasakan oleh guru membawa implikasi yang signifikan terhadap etos kerja.

\section{DAFTAR PUSTAKA}

Ananta, Henry (1994). Tingkat Etos Kerja Guru SMK di Kodya Yogyakarta dan Faktor-faklor yang Mempengaruhinya. Tesis master, tidak diterbitkan. IKIP Jakarta.

Dewey, John. (2005). Democracy and Education. Pensylvania State Electronic Classic Series Publication. [Online]. Tersedia : 
http://www.hn.psu.edu/faculty/jman is/jimspdf.htm.

Hasibuan, M. (2013). Managemen Sumber Daya Manusia. Jakarta: Bumi Aksara.

Kast, E. Fremont dan Rosenzweig, E. James. (2005). Organisasi dan Manajemen. Jakarta: Bumi Aksara.

Kistanto, N. H. (2015). Tentang Konsep Kebudayaan. Sabda, 10(2), 1-11.

Luthans, Fred. (2006). Organizational Behavior. Singapore. McGraw-Hill.

Mondy, R., Wayne, Sharplin, Arthur, and Premeux, R. Shane. (2005). Management, Concepts, Practices, and Skills (Fifth ed). Massachusetts. Silmon \& Schuster, Inc.

Makmun Muchlas. (2005). Perilaku Organisasi. Yogyakarta: Gadjah Mada University Press.

Nimran, Umar. (2005), Perilaku Organisasi. Surabaya: Citra Media.

Winardi (2005), Management Perilaku Organisasi. Bandung: PT. Citra Aditya Bakti.

Robbins, Stephen P. (2005). Organizational Behavior: Concept Controversies, Application. New Jersey: Englewood Cliff.

Schein, Edgar. H. (2005). Psikologi Organisasi. Jakarta: Midas Surya Grafindo.

Sinamo, Jansen H. (2002). Ethos 21 Etos Kerja Professional di Era Digital Global. Jakarta : Makardika.

Soeharsono Sagir. (2000). Membangun Manusia Karya. Jakarta : Pustaka Sinar Harapan.

Hormati, Theolina. (2016). Pengaruh Budaya Organisasi, Rotasi Pekerjaan Terhadap Motivasi Kerja dan Kinerja Pegawai. Jurnal EMBA, 4(2), 298-310.

Toto Tasmara. (2001). Etos Kerja Pribadi Muslim. Yogyakarta : Dana Bakti PrimaYasa. 